きさは, 径 $8 \mathrm{~mm}$, 長さ $5 \mathrm{~cm}$ でその周囲にはヒーターが巻いて ある。クロマコンの場合は（図 10)のように，パイパスコックを 閉じて気体試料導入部から夜体試料導入部へキャリアーガスを通 してその間に反応管を取付げた。反応管の大きさは前記のものと 同様である。反応管の中には，セライト $(40 \sim 80$ メッシュ) Kニ ンヒドリンを $30 \sim 50 \%$ 保持させたものを充媜せ，分析中に送入 されて来るアミノ酸に対してニンヒドリンが十分あるように、ひ

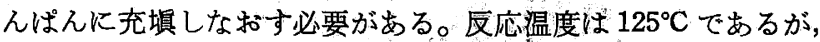
これより低い温度で反応をおこなったり，また反応管を大きくし たりすると反応生成物は一度にカラム内に送り込まれないので， 非常に幅広いピークしか得られない。良好なクロマトグラムを得 るには前記のような大きさ，温度が最適であった。アラニン水溶 液（約 $10 \mathrm{~g} / \mathrm{d} l$ ) の分析例を（図 11）に示す。先のアルデヒドの 場合と同様に おこない，カラム忙 $2 \mathrm{~m}$, 固定相として，30\%グ リセリン/C-22 (60〜80メッシュ) と 25\% シリコーングリース/ セライト (10〜30 メッシュ)を 1 対 1 の割合でつないだすのを充 媜し, カラム温度は $65^{\circ} \mathrm{C}$, 反応温度は $125^{\circ} \mathrm{C}$, 試料量は $0.05 \mathrm{ml}$ である。同様にノルパリン水溶液 $(5 \mathrm{~g} / \mathrm{d} l)$ の分析例を図 10 に 示寸。この場合の条件はアラニン水溶液の場合と同じである。最 後にアラニン，バリン，ルバリン，ロイシン，ノルロイシンの
混合物の水溶夜のガスクロマトグラムを示す（図 11）。この場合 の条件もアラニン，ノルハシリンのときと大体同じであるが，アミ ノ酸の種類が増加しているので, シリューン・グリースの割合を 大にしてグリセリンとシリコーン・グリース，1対 4 のカラムを 用いた。カラムは $4 \mathrm{~m}$, カラム温度は $65^{\circ} \mathrm{C}$ である。またこのと きはグリセリンの次にシリコーン・グリースのカラムをつないた 2 段カラムを用いたが， 1 対 4 の均一な混合物をカラムに用いて も同様の結果が得られた。

最後にノルバリン水溶液 $(6 \mathrm{~g} / \mathrm{d} l)$ とバリン水溶液 $(5 \mathrm{~g} / \mathrm{d} l)$ の 混合物について，両ピーク高比の再 現性について簡単に求めた結果を表 1 に示す。すなわち, この方法によ ってアミノ酸水溶液は定量的な取扱 いが可能で, 感度の高い検出器を用 いれば水中の微量のアミノ酸も十分

\begin{tabular}{|c|c|c|}
\hline \multicolumn{3}{|c|}{ 表 1} \\
\hline & 帪 & ピーク高皆 (ノル \\
\hline I & & $\left\{\begin{array}{l}0.67 \\
0.68 \\
0.67\end{array}\right.$ \\
\hline II & & $\begin{array}{l}0.62 \\
0.63 \\
0.65\end{array}$ \\
\hline
\end{tabular}
定量ができる。

ここではアルコール，アルデヒド，アミノ酸の水溶液の例だけ を報告したが，ま夗また応用範囲はひろく，プレカットカラムな どの考案とともに水溶液に関して，すっと広くガスクロマトグラ フィーが利用されることが期待される。

\title{
ガスクロマトグラフ法によるテルペン炭化水素類の分析（その 2)†
}

\author{
（昭 和 35 年 12 月 19 日 受 理 $)$
}

\author{
松浦多聞*・古前 恒 ${ }^{* *}$ 荒谷孝昭**・林 修一*
}

\begin{abstract}
22 種のテルペン炭华水索類のクロマトグラムを，4種の固定相 (PEG6000, TCP, squalene, squalane) Kついて検討 した。試料注入量と保持時間の関係を各炭化水素について决定し，試料量ゼロに拈ける各試料の内部標準物質 $(1,8$-シネ オール，シクロヘキサノール）に対する絶対的相対保持值を決定した。また調合試料につき各固定相を用いた場合の分離 能について検討した。その結果，いずれの固定相を用いた場合も各㟶化水素の溶出順位は大体沸点順位と一致した。また 試料注入量の增加により保持洔間が大となり，溶出順位のおそいるのほどこの傾向が顕著であった。PEG 6000 では尖鋭 なピークが得られ分離能が最もよく，試料の分解や異性化がみられず，分析所要時間が最す短い。TCP では の立体異性体の分離がなされた。 squalane は squalene よりす分離能悪く， $\beta$-ピネンの分解をとすない 4 種の固定相の らち最も性能が悪いことを見出した。
\end{abstract}

\section{1 緒 論}

$\mathrm{C}_{10}$ の不飽和化合物であるテルペン 炭化水素類には多くの化合 物があるが，これらは互に構造異性体あるいは立体異性体であっ て，物理的性質および化学的性質が類似しているばかりでなく， 天然にも合成的にも数種類の化合物が混合しているのが普通であ る。したがって，各テルペン化合物をそれぞれ単離することは非 常に困難である。しかもテルペン類は一般に熱, 空気, 光などに よって容易に変化を受けるので，せっかく分離精製した試料も純 粋の状態で保存することがほとんど不可能である。このように必 要に応じて所要の化合物を入手することが困難で，しかる性質が 非常に近似しているテルペン化合物では，高純度の試料を調製し

†本報を「ガスクロマトグラフ法によるテルペンおよび香料 成分の分析（第 2 報)」とする.

* 広島大学理学部化学教室 : 広島市東千田町.

**広島大学教養部化学教室 : 厇島市東千田町.
てそのガスクャマトグラフ的挙動を追究し，データを集積してお くことが肝要である。

前報1)においては 9 種のテルペン炭化水素を被検体とし, 7 種 の固定液相，すなわち tricresyl phosphate (TCP), squalene, high vacuum oil, Thermol, polyethylene glycol 6000 (PEG 6000), dioctyl phthalate B 括よび silicone DC 550 について, それぞれの分離能を比較し，すぐれた分離能が認められた TCP 㧊よび squalene について各テルペン炭化水素の試料注入量によ る保持時間の変化を検討して, 試料注入量をぜロに外挿した絶対 保持時間 $t_{\mathrm{R} 0}$ を決定し，これをむとにしてさらに絶対的相対保持 值 $R_{\mathrm{tR0}}$ を求めた。 未知試料の分析は通常の相対保持值を使用す ることよりる，この絶対的相対保持值の使用によっていっそう正 確な結果が期待される。

本報では 22 種のテルペン岸化水素類を被検体として, 固定液 相には前報で用いた TCP および squalene のほかに，予備実験 1）松浦, 古前, 荒谷, 林, 工化 63, 1761 (1960). 
からすぐれた性能が予想される PEG 6000 および squalane を追加して, 試料注入量による保持時間の変化を決定し, 絶 対的相対保持値を求めて前報の研究を払充した。

\section{2 結果および考察}

前報の装置（内径 $4 \mathrm{~mm}$, 長さ $3 \mathrm{~m}$ のらせん状銅製 カラ ム, 熱伝導度型検出器）を使用し，キャリアーガスにーリウ ムを用いて, 検出器のフィラメント電流は $200 \mathrm{~mA}$ 設定し て実験を行なった※1。

\section{$2 \cdot 1$ 試料注入量と保持時間との関係}

各テルペン炭化水素について試料注入量を $16.5 \mu l$ から $3.3 \mu l$ の間でいろいろに変えて測定を行ない,クロ、トグラ ムを得た。これらのクロマトグラムの原点（スタート）を重 ね合せた場合，それそれのクロマトグラムのピーク頂が前報 の図 5, 図 6 に示したと同様に一直線上に位置した。そこで この直線とクロマトグラムの基線とのなす角 $\theta$ および任意の 試料注入量の場合における見かけの保持時間を絶対保持時間

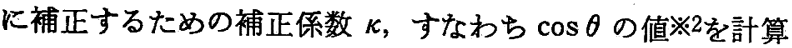
し、これを表 1 に示した。

表 1 のの值がすべて正数であることからも知られるように， いずれの固定液相の場合にもテルペン炭化水素類は試料注入量の 增加にともなって，そのクロマトグラムのピーク頂が後退し，保 持時間の伸長が認められた。しかも，この保持時間伸長の現象は 一般に保持時間の大きい化合物，すなわちより遅く溶出する $r$ テルピネン, 3,8(9)-p-メンタジェン, テルピノレン, $2,4(8)-p-$ メンタジエンなどで顕著であった。たと充ば見かけの保持時間 $t_{\mathrm{R}}$ (試料注入量 $3.3 \mu l$ ) は絶対保持時間 $t_{\mathrm{R} 0}$ に比較して, TCPを 固定相に用いた場合ではテルピノレンで 4.21 分（ $t_{R} 29.94$ 分, $t_{\mathrm{R} 0} 25.73$ 分), $3,8(9)-p$-メンタジェンで 1.96 分（ $t_{\mathrm{R}} 25.96$ 分, $t_{\mathrm{R} 0} 24.00$ 分), $2,4(8)$-p-メンタジェンで 2.11 分 ( $t_{\mathrm{R}} 30.64$ 分, $t_{\mathrm{Ro}} 28.53$ 分), squalane を用いた場合ではテルピノレンで 2.07 分 $\left(t_{\mathrm{R}} 40.05\right.$ 分, $t_{\mathrm{R} 0} 37.98$ 分) の遅れが認められた。試料注入
表 1 試料注入量の変化によるピーク頂の傾き $(\theta)$ と 絶対保持㭙閒への補正係数 $(k)$

$\overbrace{\text { 化 合 物 } \text { 固 定 相 }}^{\text {PEG } 6000} \overbrace{\theta^{\circ} \kappa_{\kappa}}^{\text {TCP }} \overbrace{\theta^{\circ}{ }_{\kappa}}^{\text {squalene }} \overbrace{\theta^{\circ} \kappa_{\kappa}}^{\text {squalane }}$

\begin{tabular}{|c|c|c|c|c|c|c|c|c|c|}
\hline \multirow{11}{*}{$\begin{array}{l}\text { 単 } \\
\text { 理 } \\
\text { 化 } \\
\text { 合 } \\
\text { 物 }\end{array}$} & $\int^{\alpha}$-pyronene & 89.5 & 0.009 & 86.4 & 0.061 & 78.3 & 0.206 & 86.7 & 0.058 \\
\hline & $\beta$-pyronene & 87.0 & 0.052 & 84.2 & 0.098 & 87.0 & 0.052 & 77.6 & 0.219 \\
\hline & trans- $p$-menthane & 89.3 & 0.006 & 84.0 & 0.105 & 87.5 & 0.043 & 82.4 & 0.133 \\
\hline & $p$-menthene- 1 & 88.2 & 0.031 & 78.3 & 0.206 & 83.7 & 0.111 & 84.0 & 0.105 \\
\hline & $\alpha$-terpinene & 86.6 & 0.059 & 80.0 & 0.176 & 85.7 & 0.075 & 86.0 & 0.070 \\
\hline & limonene & 89.0 & 0.018 & 79.0 & 0.194 & 76.6 & 0.238 & 84.8 & 0.091 \\
\hline & $\gamma$-terpinene & 82.6 & 0.129 & 73. 0 & 0.306 & 83.5 & 0.113 & 77.9 & 0.215 \\
\hline & $3,8(9)-p$-menthadiene & 86.2 & 0.068 & 61.3 & 0.538 & 82.0 & 0.141 & - & - \\
\hline & terpinolene & 83.0 & 0.123 & 55.2 & 0.696 & 69.2 & 0.379 & 66.0 & 0.445 \\
\hline & lenthadiene & 86.7 & 0.060 & 57.0 & 0.649 & 78.7 & 0.200 & 74.3 & 0.279 \\
\hline & (bornylene & 89.8 & 0.004 & 88.0 & 0.035 & 88.7 & 0.022 & 89.0 & 0.018 \\
\hline \multirow[b]{2}{*}{ 双 } & $\beta$-fenchene & 89.8 & 0.004 & 89.2 & 0.013 & 89.8 & 0.004 & 88.3 & 0.029 \\
\hline & $\alpha$-pinene & 89.0 & 0.018 & 87.6 & 0.044 & 87.7 & 0.040 & 87.8 & 0.039 \\
\hline 理 & $\alpha$-fenchene & 89.3 & 0.006 & 86.0 & 0.070 & 89.0 & 0.018 & 88.0 & 0.035 \\
\hline \multirow[b]{2}{*}{ 合 } & camphene & 88.5 & 0.026 & 85.6 & 0.074 & 87.0 & 0.052 & 88.0 & 0.035 \\
\hline & $\beta$-pinene & 88.2 & 0.031 & 分 & 解 & $87.6 *$ & 0.044 & 分 & \\
\hline \multirow{2}{*}{$\begin{array}{l}\text { 合 } \\
\text { 物 }\end{array}$} & isocamphane & 87.6 & 0.044 & 79.3 & 0.188 & 86.0 & 0.070 & 80.0 & 0.176 \\
\hline & trans-pinane & 87.0 & 0.052 & 77.6 & 0.219 & 82.6 & 0.129 & 84.6 & 0.100 \\
\hline • & cis-pinane & 86.2 & 0.068 & 80.0 & 0.176 & 85.0 & 0.089 & 85.0 & 0.088 \\
\hline \multirow{3}{*}{$\begin{array}{l}z \\
\text { 至 } \\
\text { 他 }\end{array}$} & tricyclene & 89.0 & 0.018 & 87.8 & 0.037 & 88.2 & 0.034 & 88.2 & 0.031 \\
\hline & myrc & 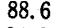 & 0.027 & 83.0 & 0.123 & 88.8 & 0.024 & 84.0 & 0.105 \\
\hline & p-cymene & 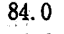 & 0.105 & 68.6 & 0.392 & 79.3 & 0.188 & 82.6 & 0.129 \\
\hline \multirow{2}{*}{\multicolumn{2}{|c|}{ 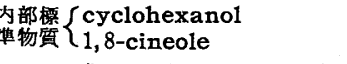 }} & $\begin{array}{l}69.0 \\
84 ?\end{array}$ & 0.384 & 70.4 & 0.357 & 85.0 & 0.089 & $\begin{array}{l}88.8 \\
89.0\end{array}$ & 0.022 \\
\hline & & & & 72.9 & 0.308 & 80.4 & 0.169 & 89.0 & 0.018 \\
\hline
\end{tabular}

* 前報表 2 で分解を起すとあるのは印刷の兂りである

量を $3.3 \mu l$ よりも多く用いた場合には，見かけの保持時間と絶 対保持時間との間にはさらに大きな差が生じるわけであるから, 未知試料の分析に括いてこの点に留意を急ると予想外の労力をつ いやし，かつ誤った結果をまねくもととなる。

\section{$2 \cdot 2$ 相対保持値と絶対保持値}

前報に拈けると同様に 1,8 -シネオールあるいはシクロヘキサ ノールを内部標準物質に用いて，各テルペン炭化水素の絶対的相 対保持值 $R_{\mathrm{tR} 0}$ を決定した。すなわち被検体と内部標準物質の見 かけの保持時間にそれぞれ前述の補正を施して絶対保持時間を求 め, これから絶対的相対保持値すなわち被検体の内部標準物質に 対する比を算出した。表 2 に絶対的相対保持值と $3.3 \mu l$ ずつの 等量混合物で求めた通常の相対保持值 $R_{\mathrm{tR}}$ とを示した。

表 2 において PEG 6000 固定相の場合の $\gamma$-テルピネンと 3,8

表 2 相対保持值 $\left(R_{\mathrm{tR}}\right)$ と絶対的相対保持值 $\left(R_{\mathrm{tRO}}\right)$.

\begin{tabular}{|c|c|c|c|c|c|c|c|c|c|c|c|c|c|c|c|c|c|c|}
\hline & & 固 定 相 & & & 6000 & & & & $\mathrm{CP}$ & & & squ & lene & & & & ualane & \\
\hline & & 内部標花物留 & $1,8-c i$ & neole & ycloh & exanol & $1,8-\mathrm{c}$ & ineole & cycloh & xanol & $1,8-\mathrm{ci}$ & eole & cycloh & exanol & $1,8-\mathrm{ci}$ & neole & cycloh & xano \\
\hline No & 1 & 化 合 物 & $\overparen{R_{\mathrm{tR}}}$ & $R_{\mathrm{tRo}}$ & $R_{\mathrm{tR}}$ & $R_{\mathrm{tR0}}$ & $\widetilde{R_{\mathrm{tR}}}$ & $R_{\mathrm{tRO}}$ & $R_{\mathrm{tR}}$ & $R_{\mathrm{tRo}}$ & $R_{\mathrm{tR}}$ & $R_{\mathrm{tR0}}$ & $R_{\mathrm{tR}}$ & $R_{\mathrm{tRo}}$ & $R_{\mathrm{tR}}$ & $R_{\mathrm{tRo}}$ & $\overparen{R_{\mathrm{tR}}}$ & $R_{\mathrm{tR} 0} 1$ \\
\hline $\begin{array}{r}12 \\
3 \\
4 \\
5 \\
6 \\
7 \\
8 \\
9 \\
10\end{array}$ & $\begin{array}{l}\text { 単 } \\
\text { 㺺 } \\
\text { 化 } \\
\text { 合 } \\
\text { 物 }\end{array}$ & $\left\{\begin{array}{l}\alpha \text {-pyronene } \\
\beta \text {-pyronene } \\
\text { trans- } p \text {-menthane } \\
p \text {-menthene- } 1 \\
\alpha \text {-terpinene } \\
\text { limonene } \\
\gamma \text {-terpinene } \\
3,8(9) \text { - } p \text {-menthadiene } \\
\text { terpinolene } \\
2,4(8) \text { - } p \text {-menthadiene }\end{array}\right.$ & $\begin{array}{l}0.38 \\
0.57 \\
0.41 \\
0.65 \\
0.80 \\
0.96 \\
1.16 \\
1.25 \\
1.35 \\
1.48\end{array}$ & $\begin{array}{l}0.43 \\
0.65 \\
0.46 \\
0.74 \\
0.89 \\
1.09 \\
1.30 \\
1.26 \\
1.52 \\
1.60\end{array}$ & $\begin{array}{l}0.15 \\
0.24 \\
0.17 \\
0.27 \\
0.33 \\
0.40 \\
0.48 \\
0.51 \\
0.56 \\
0.61\end{array}$ & $\begin{array}{l}0.18 \\
0.27 \\
0.19 \\
0.31 \\
0.37 \\
0.45 \\
0.54 \\
0.52 \\
0.63 \\
0.66\end{array}$ & $\begin{array}{r}0.33 \\
0.54 \\
0.36 \\
0.61 \\
0.73 \\
0.78 \\
1.06 \\
1.11 \\
1.28 \\
\Delta 1.31\end{array}$ & $\begin{array}{l}0.32 \\
0.58 \\
0.37 \\
0.63 \\
0.75 \\
0.80 \\
1.07 \\
1.11 \\
1.19 \\
1.32\end{array}$ & $\begin{array}{l}0.28 \\
0.47 \\
0.31 \\
0.53 \\
0.63 \\
0.68 \\
0.91 \\
0.96 \\
1.10 \\
1.13\end{array}$ & $\begin{array}{l}0.28 \\
0.51 \\
0.32 \\
0.55 \\
0.66 \\
0.70 \\
0.94 \\
0.97 \\
1.04 \\
1.16\end{array}$ & $\begin{array}{r}0.47 \\
0.59 \\
0.55 \\
0.73 \\
0.76 \\
1.01 \\
\Delta 0.98 \\
1.15 \\
1.42 \\
\Delta 1.27\end{array}$ & $\begin{array}{l}0.47 \\
0.60 \\
0.55 \\
0.73 \\
0.75 \\
1.00 \\
0.97 \\
1.13 \\
1.41 \\
1.27\end{array}$ & $\begin{array}{l}0.98 \\
1.23 \\
1.15 \\
1.52 \\
1.58 \\
2.10 \\
2.04 \\
2.40 \\
2.96 \\
2.65\end{array}$ & $\begin{array}{l}1.02 \\
1.30 \\
1.20 \\
1.59 \\
1.63 \\
2.18 \\
2.11 \\
2.46 \\
3.06 \\
2.76\end{array}$ & $\begin{array}{r}\Delta 0.48 \\
0.64 \\
0.87 \\
0.99 \\
0.85 \\
\Delta 0.97 \\
0.90 \\
\Delta- \\
\triangle 1.35 \\
\triangle 1.32\end{array}$ & $\begin{array}{l}0.47 \\
0.63 \\
0.85 \\
0.97 \\
0.85 \\
0.97 \\
0.87 \\
- \\
1.28 \\
1.27\end{array}$ & $\begin{array}{l}1.34 \\
1.79 \\
2.42 \\
2.75 \\
2.38 \\
2.72 \\
2.52 \\
-\overline{7} \\
3.76 \\
3.68\end{array}$ & $\begin{array}{l}1.32 \\
1.77 \\
2.38 \\
2.72 \\
2.38 \\
2.73 \\
2.44 \\
- \\
3.60 \\
3.56\end{array}$ \\
\hline $\begin{array}{l}11 \\
12 \\
13 \\
14 \\
15 \\
16 \\
17 \\
17 \\
18 \\
19\end{array}$ & $\begin{array}{l}\text { 双 } \\
\text { 環 } \\
\text { 化 } \\
\text { 合 } \\
\text { 物 }\end{array}$ & $\left\{\begin{array}{l}\text { bornylene } \\
\beta \text {-fenchene } \\
\alpha \text {-pinene } \\
\alpha \text {-fenchene } \\
\text { camphene } \\
\beta \text {-pinene } \\
\text { isocamphane } \\
\text { trans-pinane } \\
\text { cis-pinane }\end{array}\right.$ & $\begin{array}{l}0.34 \\
0.28 \\
0.34 \\
0.43 \\
0.44 \\
0.55 \\
0.43 \\
0.41 \\
0.43\end{array}$ & $\begin{array}{l}0.38 \\
0.33 \\
0.37 \\
0.49 \\
0.47 \\
0.61 \\
0.46 \\
0.43 \\
0.46\end{array}$ & $\begin{array}{l}0.14 \\
0.11 \\
0.14 \\
0.18 \\
0.18 \\
0.23 \\
0.18 \\
0.17 \\
0.18\end{array}$ & $\begin{array}{l}0.16 \\
0.14 \\
0.15 \\
0.20 \\
0.19 \\
0.25 \\
0.19 \\
0.18 \\
0.19\end{array}$ & $\begin{array}{l}0.25 \\
0.30 \\
0.32 \\
0.37 \\
0.40 \\
\\
0.39 \\
0.34 \\
0.38\end{array}$ & $\begin{array}{r}-0.25 \\
0.30 \\
0.32 \\
0.38 \\
0.39 \\
\text { 分 } \\
0.39 \\
0.33 \\
0.36\end{array}$ & $\begin{array}{l}0.21 \\
0.26 \\
0.28 \\
0.32 \\
0.35 \\
\text { 解 } \\
0.34 \\
0.29 \\
0.33\end{array}$ & $\begin{array}{l}0.22 \\
0.26 \\
0.28 \\
0.33 \\
0.35\end{array}$ & $\begin{array}{l}0.42 \\
0.33 \\
0.50 \\
0.47 \\
0.59 \\
0.70 \\
0.60 \\
0.52 \\
0.57\end{array}$ & $\begin{array}{l}0.44 \\
0.33 \\
0.53 \\
0.47 \\
0.60 \\
0.71 \\
0.59 \\
0.50 \\
0.58\end{array}$ & $\begin{array}{l}0.89 \\
0.69 \\
1.12 \\
0.98 \\
1.23 \\
1.46 \\
1.26 \\
1.08 \\
1.19\end{array}$ & $\begin{array}{l}0.96 \\
0.72 \\
1.12 \\
1.02 \\
1.30 \\
1.54 \\
1.28 \\
1.10 \\
1.26\end{array}$ & $\begin{array}{l}0.45 \\
0.51 \\
0.56 \\
0.53 \\
0.61 \\
\\
0.80 \\
0.85 \\
0.90\end{array}$ & $\begin{array}{l}0.44 \\
0.51 \\
0.56 \\
0.53 \\
0.60 \\
\text { 分 } \\
0.80 \\
0.85 \\
0.90\end{array}$ & $\begin{array}{l}1.25 \\
1.42 \\
1.57 \\
1.48 \\
1.71 \\
\text { 解 } \\
2.23 \\
2.37 \\
2.52\end{array}$ & $\begin{array}{l}1.23 \\
1.42 \\
1.56 \\
1.48 \\
1.68 \\
\\
2.23 \\
2.38 \\
2.54\end{array}$ \\
\hline $\begin{array}{l}20 \\
21 \\
22\end{array}$ & $\begin{array}{l}\text { そ } \\
\text { 他 }\end{array}$ & $\left\{\begin{array}{l}\text { tricyclene } \\
\text { myrcene } \\
p \text {-cymene }\end{array}\right.$ & $\begin{array}{l}0.33 \\
0.71 \\
1.33\end{array}$ & $\begin{array}{l}0.31 \\
0.80 \\
1.40\end{array}$ & $\begin{array}{l}0.14 \\
0.29 \\
0.55\end{array}$ & $\begin{array}{l}0.13 \\
0.33 \\
0.58\end{array}$ & $\begin{array}{l}0.29 \\
0.58 \\
1.08\end{array}$ & $\begin{array}{l}0.30 \\
0.59 \\
1.07\end{array}$ & $\begin{array}{l}0.25 \\
0.50 \\
0.93\end{array}$ & $\begin{array}{l}0.27 \\
0.52 \\
0.94\end{array}$ & $\begin{array}{l}0.48 \\
0.58 \\
1.00\end{array}$ & $\begin{array}{l}0.49 \\
0.58 \\
1.01\end{array}$ & $\begin{array}{l}1.00 \\
1.21 \\
2.08\end{array}$ & $\begin{array}{l}1.06 \\
1.26 \\
2.19\end{array}$ & $\begin{array}{r}0.51 \\
\Delta 0.64 \\
0.91\end{array}$ & $\begin{array}{l}0.50 \\
0.64 \\
0.86\end{array}$ & $\begin{array}{l}1.43 \\
1.80 \\
2.53\end{array}$ & $\begin{array}{l}1.40 \\
1.79 \\
2.42\end{array}$ \\
\hline 23 & 4 & $\left\{\begin{array}{l}\text { cyclohexanol } \\
1,8 \text {-cineole }\end{array}\right.$ & $\begin{array}{l}2.43 \\
1.60\end{array}$ & $\begin{array}{l}2.42 \\
1.00\end{array}$ & $\begin{array}{l}1.00 \\
0.41\end{array}$ & $\begin{array}{l}1.00 \\
0.41\end{array}$ & $\begin{array}{l}1.16 \\
1.00\end{array}$ & $\begin{array}{l}1.14 \\
1.00\end{array}$ & $\begin{array}{l}1.00 \\
0.86\end{array}$ & $\begin{array}{l}1.00 \\
0.88\end{array}$ & $\begin{array}{l}0.48 \\
1.00\end{array}$ & $\begin{array}{l}0.46 \\
1.00\end{array}$ & $\begin{array}{l}1.00 \\
2.09\end{array}$ & $\begin{array}{l}1.00 \\
2.18\end{array}$ & $\begin{array}{l}0.36 \\
1.00\end{array}$ & $\begin{array}{l}0.36 \\
1.00\end{array}$ & $\begin{array}{l}1.00 \\
2.79\end{array}$ & $\begin{array}{l}1.00 \\
2.81\end{array}$ \\
\hline
\end{tabular}


(9)-p-メンタジェン, $\alpha$-フェンケンとカンフェン, トリシクレン と $\beta$ フェンケン, または squalene 固定相の場合のリモネンと p-シメン， $\alpha$-ピネンと trans-ピナンその他など， $R_{\mathrm{tR}}$ と $R_{\mathrm{tR0}}$ では溶计順位が逆転した。これは試料注入量の多少による保持時 間の変化が各化合物について一様でないことに基つく。保持時間 の接近した成分を分析する場合に等量混合物では分離したクロマ トグラムが得られるが，混合割合が甚しく異なると分離が不完全 で重複したピークしか得られないことは，われわれが日常しばし ば経験するところである。このピークの重複もその原因の一つは 試料注入量による保持時間の変化にもとづくものであろう。

\section{$2 \cdot 3$ 各種カラムの分離能}

図 1 は 4 種の固定相をつめたカラムについての各テルペン炭化 水素の絶対的相対保持値 $R_{\mathrm{tRO}}$ （内部標準物質に 1,8-シネオール を使用した場合）の分布を示したものであるが，そのうちaの部 分は固定液相の相互の関係を見るためにテルペン化合物の構造に

a

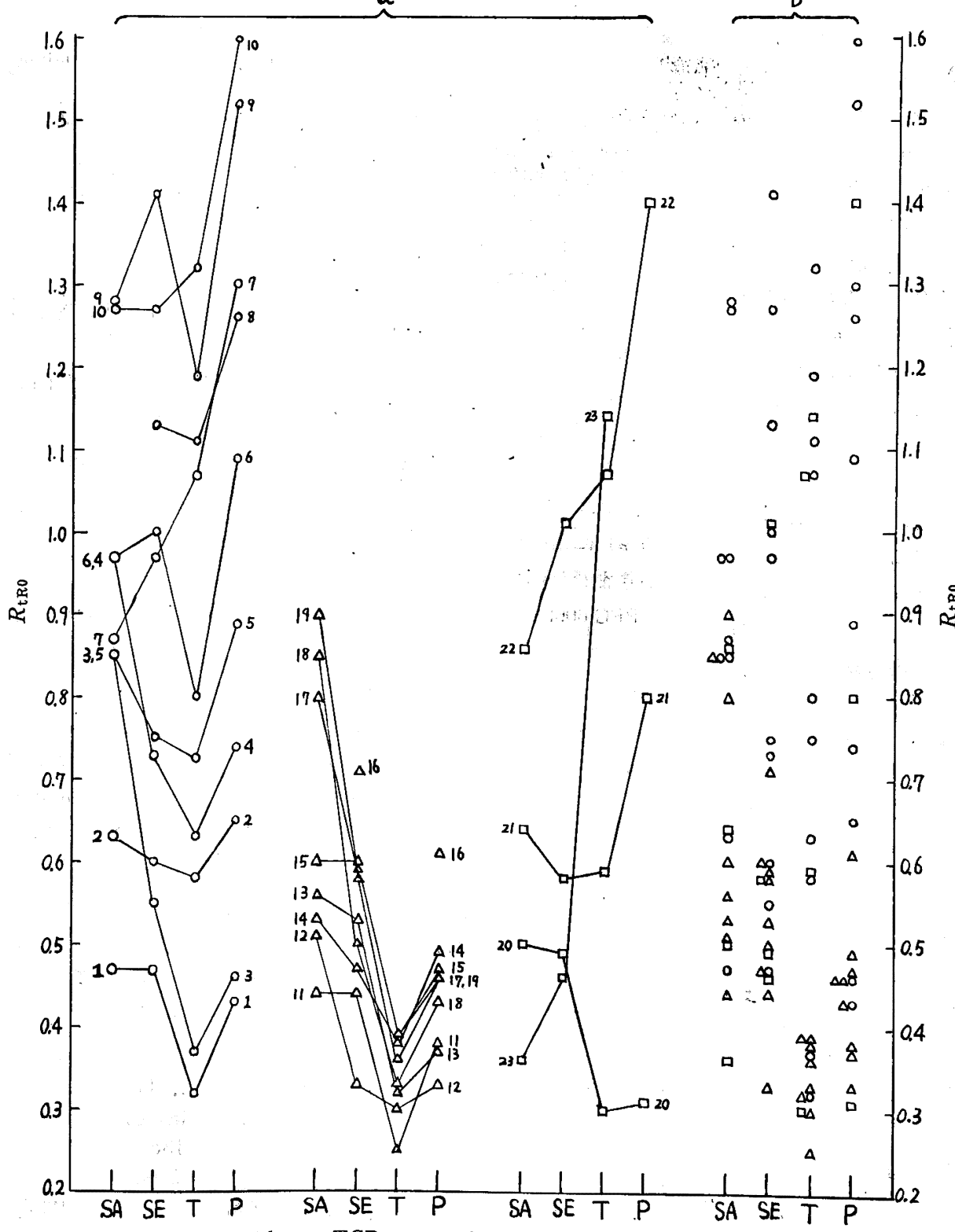

図 1 squalane, squalene, TCP および PEG 6000 飞括ける絶対的相対保持值の分布 SA : squalane, SE : squalene, T : tricresyl phosphate, P : PEG 6000 $O$ 単環化合物 $\Delta$ 双環化合物 口

$a$ の部分の数字は表 2 の化合物を示す番号である。1，8-Cineole を内部標諆物留とした。 よって三つに区分し，bの部分は全体をまとめて比較した。テル ペン炭化水素類の溶出順序は squalane, squalene, TCP および PEG 6000 によってほとんど変化はなく，大体沸点順に溶比する。 これは炭化水素が固定液相の極性に関係のうすい化舍物であるこ とに起因する。ただし $p$-メンタン， $\gamma$-テルピネン， $\alpha$-ピネン， pーシメンおよびシクロへキサノールでは固定液相によって溶出順 序にかなりの変動が認められる。

squalane-ケイソウ土カラム Tenney'2) squalane を固定液 相として用いて，脂肪族炭化水素の分析に良好な結果を与えたと 報告しているが, 本実験条件では $\alpha$-ピロネン,リモネン, 3,8(9)p-メンタジェン，テルピノレン， 2, 4(8)-p-メンタジェンおよび ミルセンなど（表 2 中の $\Delta$ 印を付した化合物）は幅の広いピーク を与学るので，保持時間の正確な決定は困難であった。とくに $3,8(9)-p$-メンダジェンではこの傾向が甚だしい。

図 1 の b に見られるよらに, 単環テルペン炭化水素類では $R_{\mathrm{tro}}$ は4 種の固定液相の5ち squalane の場 合が最も密集しているが，双環テルペン 炭化水素類に括いては単環テルペン炭化 水素の場合よりも分散の程度は良好であ った。しかし全般的にこの固定液相は他 のものと比較して分離が少る。その上 $\beta-$ ピネンはこの固定相で分解するので，こ れを含む試料の分析には十分な注意が必 要である。

squalane-ケイソウ土カラムこのカ ラムについては一部前報1で報告したが, squalane の場合に比較して幾分 $R_{\mathrm{tR0}}$ が 分散している（図 1 )。 $\beta$-ピネンの 分解 も認められなかったので，テルペン炭化 水素類の分析には squalane よりもすぐ れた固定液相である。しかし

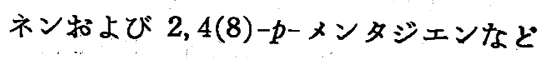
はやや幅の広いピークを与えた。

8 種のテルペン化合物で調製した混合 試料（ $\alpha$-ピネン $13.2 \%$ ，カンフェン $11.5 \%, \beta$ ーピネン $12.2 \%$, リモネン

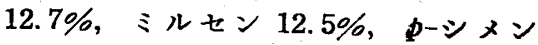
13. 1\%, 2,4(8)-p-メンタジェン13.2\%, 1,8-シネオール 11.6\%) のクロマトグ ラムは図2であるが，p-シメン（ $R_{\mathrm{tRo}}$ 1.01）と 1,8-シネオール ( $\left.R_{\mathrm{tR0}} 1.00\right)$, $\beta-$ ピネン $\left(R_{\mathrm{tRO}} 0.71\right)$ とミルセン $\left(R_{\mathrm{tRO}}\right.$ 0.58）の分離は出来なかった。 tricresyl phosphate-ケイソウ土カラ 厶すべてのテルペン炭化水素類がかな り鋭いピークを与え（前報参照)， $R_{\mathrm{tRO}}$ にす分散がみられる（四 1)。

ラネーニッケルを触媒に用いリモネン の水素添加によって調製した $\boldsymbol{p}$-メンタ ンがこの固定相によって $R_{\mathrm{tRO}} 0.37$ と

2) H. M. Tenney, Anal. Chem. 30, 2 (1958). 


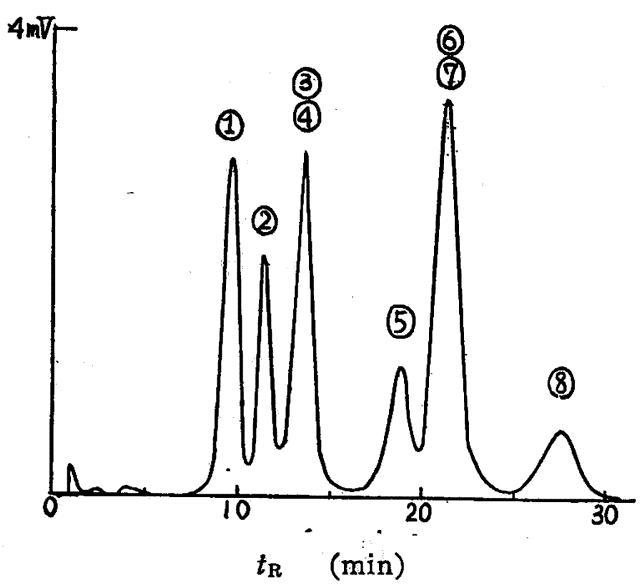

図 2 テルペン炭化水素混合物の squalene カラム によるクロマトグラム

$\left(120^{\circ} \mathrm{C}, 30 \mathrm{~m} l / \mathrm{min}, 200 \mathrm{~mA}, 4 \mathrm{mV}, 3.3 \mu l\right)$; (1)๙-ピネン, (2)カンフェ

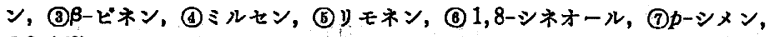
(82,4(8)-p-メンタシシンン

0.41 の二つのピークに分離された。各ピーク部分を分別捕集し, IR スペクトル分析を行なった。その結果 $R_{\mathrm{tR} 0} 0.37$ のピークは trans-p-メンタンであり，0.41 のピークは cis-p-メンタンであ ることを API 赤外データ No. 1650 拈よび No. 1649 にそれぞ れ一致することより確めた。 PEG 6000-ケイソウ土カラムの場合 にも trans-p-メンタンと cis-p-メンタンの分離が認められた。 しかしその場合の両ピークは極めて接近して括り, 試料注入量の 增加ととあに cis 体のピークはしだいに主成分である trans 体の ピークに吸収されて現われなくなった。したがって $p$-メンタン の立体異性体の分離には TCP が好適である。な拉 squalane あ るいは squalene カラムによっては p-メンタンの trans体と cis 体との分離は認められなかった。

polyethylene glycol 6000-ヶイソウ土カラム いずれのテル ペン炭化水素も鋭いピークを与え, しかも $R_{\mathrm{tR0}}$ が他の固定相に 比較して最もよく分散している（図 1 )。squalene-ケイソウ土カ ラムの項で述べた調合試料の $100^{\circ} \mathrm{C}$ に持けるクロマトグラムは四 3 であって，8成分がよく分離した。また不安定な $\beta$-ピネンの 分解も認められないので，テルペン炭化水素類の分析には PEG 6000 は最も適した固定液相である。

カラム温度とガス流量を変えた場合の 分離能3) と理論段数4)を

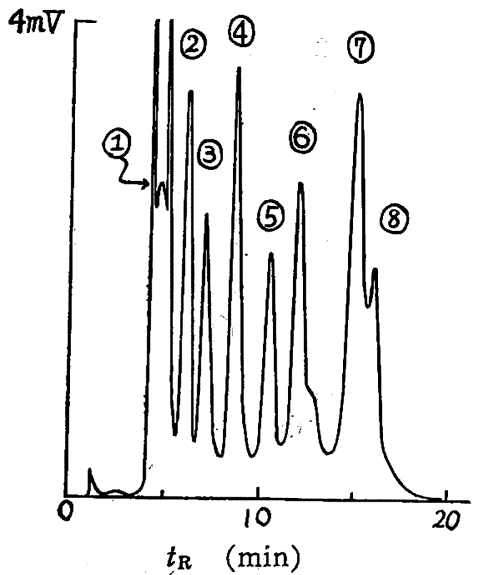

因 3 テルペン炭化水素混合物の PEG 6000 カラムによる

$$
\text { クロマトグラえ }
$$

$\left(100^{\circ} \mathrm{C}, 30 \mathrm{ml} / \mathrm{min}, 200 \mathrm{~mA}, 4 \mathrm{mV}, 3.3 \mu l\right)$

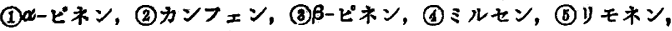

(101,8-シネオール, (7)p-シメン, (8)2,4(8)-p-メンタジェン
表 3 カラム温度とガス流量の变化によ. 表 3 に示した。 る分離能々理論段数

\begin{tabular}{|c|c|c|c|}
\hline 温 & $\begin{array}{c}\text { 流 } \\
(\mathrm{m} l / \mathrm{min})\end{array}$ & 分 離 能* & 理論段数** \\
\hline 100 & 60 & 1. 45 & - 831 \\
\hline 100 & 30 & 1.55 & 1261 \\
\hline 80 & 60. & 1. 25 & 914 \\
\hline 80 & 30 & 1.40 & 1181 \\
\hline
\end{tabular}

$100^{\circ} \mathrm{C}, 30 \mathrm{~m} l / \mathrm{min} の$ 条件が分離能および理 諭段数ともに最もすぐ れている。その際の分 析所要時間は最後に溶 出する 2,4(8)-p-メン タジェンに怙いても 16 分にすぎない。しかしこの固定相に拈い てもなお $\alpha$-ピロネンと trans-ピナン, trans-p-メンタンとイソ カンファン， cis-ピナンは同一の $R_{\mathrm{tr} 0}$ を示し分離し得なかった。 またこの固定相は $100^{\circ} \mathrm{C} て ゙$ 使用しても，使用回数が重なるにつれ 七固定液相が溶出し濃度が減少する。

\section{3 実験}

\section{$3 \cdot 1$ クロマトクラムの作製条件}

表 4 の条件でクロマトグラムをつくった。

表 4 クロマトグラムの測定条件

PEG 6000 TCP squalene squalane

固定液相/担体（更量） $1 / 5 \quad 1 / 5 \quad 1 / 5 \quad 1 / 5^{*}$

$\begin{array}{lllll}\text { 温 }\left({ }^{\circ} \mathrm{C}\right) & 100 & 100 & 120 & 120\end{array}$

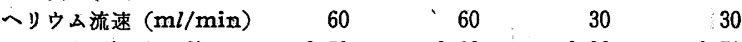

$\begin{array}{llllll}\text { 入口压力 }\left(\mathrm{kg} / \mathrm{cm}^{2}\right) & 0.70 & 0.63 & 0.36 & 0.71\end{array}$

出口正力常压常压常压常压

* 前報工化 63,1765 (1960) 飞記した squalene-ケイソウ土の蕞度 （4.9\%）は 1/5 の非りである。

\section{$3 \cdot 2$ 固定相の調製}

TCP-ケイソウ土执よび squalene-ケイソウ土：前報1)のと拈り に調製した。

squalane-ケイソウ土: 市販 squalene をアセトンから数回再 結晶して精製し5), これをニッケルーケイソウ土触媒を用いてオー トクレーブ中で水素添加して squalane を調製した。bp 239 243 ${ }^{\circ} \mathrm{C} / 6.5 \mathrm{mmHg}, n_{\mathrm{D}}^{25} 1.4508, d_{4}^{25} 0.8091$ 。この石油エーテル溶液 (5\%) に市販担体 Shimalite ${ }^{3}$ (28〜 48 mesh) を浸して, 時々 かきまぜながら水浴上で加熱し溶媒を蒸散させた。

PEG6000-ケイソウ土: Carbide \& Carbon Chemicals 社の PEG-6000 をアセトンに溶かし（5\% 溶液）， squalane の場合と 同様に Shimalite に塗布して調製した。

\section{$3 \cdot 3$ 被検テルペン試料の調製}

ボルニレン, トリシクレン, $\alpha$-ピロネン, $\alpha$-ピネン, カンフ エン, $\beta$-ピネン, リモネン, $p$-シメン, テルピノレン, $1,8-$ シネ オール怙よびシクロヘキサノール：前報1)の方法によって調製し た。

$\alpha$-テルピネン， $\gamma$-テルピネン拈よび 2,4(8)-p-メンタジェン: リモネンと硫酸 $(4 \mathrm{~N})$ アルコール溶液との等量混合物を $84^{\circ} \mathrm{C}$ で 5 時間はげしくかきまぜ,リモネンを異性化させた6)。反応油を炭 酸水素ナトリウムの水溶液 (3\%) で中和，乾燥して減王下に精密

3) $R=2 \Delta y /\left(Y_{\mathrm{a}}+Y_{\mathrm{b}}\right) \mathrm{D}$. H. Desty, "Gas Chromatography" p. xi (1958), Butterworths Sci. Publ., London.

4) $n=16\left(t_{x} / \Delta t_{x}\right)^{2} \quad$ V. J. Coates, et al, "Gas Chromatography” p. 316 (1958), Academic Press Inc., Publ., New York.

5) K. J. Sax, F. H. Stross, Anal. Chem. 29, 1700 (1957).

※3 ケイソウ土を主成分とする。

6) 林, 瑇ロ,“・モネンに対する硫酸酸性アルコールの作用” 日化第 9 年会（1956 年 4 月）预よび日化中国四国支部第 21 常会 (鳥取) (1957 年 5 月) 講演. 
分留をくりかえし $\alpha$-テルピネン $\left(\mathrm{bp} 79^{\circ} \mathrm{C} / 33 \mathrm{mmHg}, n_{\mathrm{D}}^{25} 1.4772\right.$, $\left.d_{4}^{26} 0.8444, \lambda_{\max }^{\text {aln }} 265 \mathrm{~m} \mu \varepsilon 7,010\right), \gamma$-テルピネン留分 (bp 85〜 $88^{\circ} \mathrm{C} / 33 \mathrm{mmHg}$ ) 拉よび $2,4(8)-p$-メンタジェン (bp $89 \sim 90^{\circ} \mathrm{C} /$ $\left.33 \mathrm{mmHg}, n_{\mathrm{D}}^{2 \mathrm{~b}} 1.4947, \quad d_{4}^{26} 0.8525, \lambda_{\max }^{\text {alc }} 244 \mathrm{~m} \mu \varepsilon 20,680\right)$ を 得た。 $r$-テルピネン留分はさらに無水マレイン酸を加えて $80^{\circ} \mathrm{C}$ に40分間加熱して混入している $2,4(8)$ - $p$-メンダジェンを除き7), 精留して ケ-テルピネン (bp 85〜86 ${ }^{\circ} \mathrm{C} / 31.5 \mathrm{mmHg}, n_{\mathrm{D}}^{26} 1.4792$, $\left.d_{4}^{26} 0.8499\right)$ とした。

$3,8(9)-p$-メンタジェン: $\alpha$-ブロムプロピオン酸エチルと 4-メ チルシクロヘキサノンの縮合物を水素化リチウムアルミニウムで 還元して 4,9-p-メンタンジオールを合成し,このジアセテートを $460^{\circ} \mathrm{C}$ で熱分解した ${ }^{8)}$ 。熱分解生成物は炭酸ナトリウム水溶液,つ いで水で洗い減圧蒸留した。 bp $74 \sim 75^{\circ} \mathrm{C} / 20 \mathrm{mmHg}, n_{\mathrm{D}}^{25} 1.4902$, $d_{4}^{25} 0.8530, \lambda_{\max }^{\mathrm{ale}} 234 \mathrm{~m} \mu \varepsilon 16,800$ 。

p-メンタン：リモネンをニッケルーケイソウ土触媒によりオー トクレーブ中で水素添加し $\left(150^{\circ} \mathrm{C} ， 5\right.$ 時間) 精留した。bp 168〜 $170^{\circ} \mathrm{C}, n_{\mathrm{D}}^{26} 1.4396, d_{4}^{25} 0.8010$ 。IR スペクトル分析拉よびガス クロマトグラフ分析により trans-p-メンタンに少量の.cis-p-メ

7) 林, 日化 80, 331 (1959).

8) H. E. Eshinazi, H. Pines, J. Org. Chem. 20, 1666 (1955).

※4 再製樟脳 $\mathrm{KK}$ の提供による。
ンタンが混入していることを認めた。

p-メンテン-1：リモネンにラネーニッケルを触媒としてオート クレーブ中で常温加圧水添してリモネン $1 \mathrm{~mol}$ につき水素 $1 \mathrm{~mol}$ の割合で水素を吸収させた。bp 176 $177^{\circ} \mathrm{C}, n_{\mathrm{D}}^{25} 1.4562, d_{4}^{25} \mathrm{O} .8191$ ， $[\alpha]_{\mathrm{D}}+109.08^{\circ}$ 。

$\beta$ ーピロネン: $\alpha$-ピネンの熱分解生成物》の精密分留をくりが した。 bp 70 71 ${ }^{\circ} \mathrm{C} / 32.5 \mathrm{mmHg}, n_{\mathrm{D}}^{2 \mathrm{~b}} 1.4782, d_{4}^{28} 0.8415, \lambda_{\max }^{\text {alc }}$ $262 \mathrm{~m} \mu \varepsilon 3,189)$ 。

$\alpha$-フェンケンおよび $\beta$ ーフェレン※4: $\alpha$-フェンキルフルョー ルを硫酸水素カリウムとともに油浴上 $\left(190 \sim 200^{\circ} \mathrm{C}\right)$ で加熱脱水 させ，その生成物を精密分留した。 bp $155 \sim 156^{\circ} \mathrm{C}, n_{\mathrm{D}}^{25} 1.4702$, $d_{4}^{25} 0.8625, \alpha_{\mathrm{D}}^{80}-15.5^{\circ}$, bp $151 \sim 152^{\circ} \mathrm{C}, n_{\mathrm{D}}^{26} 1.4645, d_{4}^{25} 0.8590^{\circ}$ ミルセン：ベイ油をくりかえし減圧分留した。 bp $65.5^{\circ} \mathrm{C} ， n_{\mathrm{D}}^{25}$ $1.4612, d_{4}^{26} 0.7906$ 。

ピナン : $\alpha$-ピネンをラネーニッケル触媒で接触還元した生成 物を精留した。bp $165 \sim 166^{\circ} \mathrm{C}, n_{\mathrm{D}}^{20} 1.4654, d_{4}^{20} 0.8630$ 。

イソカンファン※5: カンフェンをラネーニッケル触媒により $60^{\circ} \mathrm{C}$ で接触還元した。 $\mathrm{mp} 63.5 \sim 64.8^{\circ} \mathrm{C}$ 。

（昭和 35 年 4 月, 日化第 13 年会一部講演)

本研究を行ならにあたり実験火協力された藤原光浐君に深謝し ます。

\title{
ガスクロマトクラフ法における分析試料におよぼす各種担体の接触作用 †
}

\author{
(昭 和 36 年 1 月 10 日受理)
}

\author{
松浦多聞* ・荒谷孝昭 ${ }^{* *}$ ・古前 恒 ${ }^{* *}$ ・林 修一*
}

\begin{abstract}
裸担体の分析試料におよぼす作用を明らかにする目的で，市眅担体および処理方法の異なる水晶粉末，パイレックスガ ラス粉末，担体用レンガ粉末，イソライト N-4 レンガ粉末など.14 種を用いて，50 種の化合物のクロマトグラムを測定 した。

実験は裸担体をつめたカラムのつぎに同定用カラムを直列に連結して行なった。

硝酸処理した水晶粉末では分析試料に対する接触作用が認められなかった。市販担体などではほとんどすべての化合物 飞接触作用が認められ，若干の化合物化吸着作用も認められた。
\end{abstract}

\section{1 緒 論}

テルペン類は酸あるいは粘土などによって非常に変化を受け易 い化合物1)であるが，著者らはさきに $\beta$-ピネンが〔市販担体 ITCP」固定相によって分解されることを指摘した2)。他の研究者 らによっても精油成分は Sterchamol あるいは耐火レンガ製担体 によって，幾分脱水縮合あるいは分解を受けるようである

† 本報を「ガスクロマトグラフ法によるテルペン化合物およ び香料成分の分析（第 3 報)」とする.

*公島大学理学部化学教室：広島市東千田町.

** 広島大学教養部化学教室 : 広島市東千田町.

1）たとえば G. Egloff, G. Hulla, V.I. Komarewsky, "Isomerization of Pure Hydrocarbons" p. 139 (1942) Reinhold Publish. Corp., New York.

2) 松浦, 古前, 荒谷, 林, 工化 63，1761 (1960).

3) Y. R. Naves, J. Soc. Cosmetic Chemists 9, 101 (1958).

4) G. P. Cartoni, A. Liberti, J. Chromatography 3, 121 (1960).
か， $\boldsymbol{\alpha}$-ピネンはカンフェンに異性化される5)などと報告されてい る。著者らの本研究が終了した直後にす Lukeš ら (6)はケイウ土 には $\alpha$-ピネンを $\beta$-ピネンに異性化させる作用があるが，白色 タイル粉末にはこのような作用がないからこれを担体として使用 することを推奖した。

また今日一般にガスクロマトグラフ用担体として用いられてい る Celite 5457)，米国製耐火レンガ $\mathrm{C}-22^{8}$ ), Sterchamol No. 229), Chromosorb C-44857 あるいは C-4856010) などはみなケイ

5) D. H. Desty, "Gas Chromatography" p. 214 (1958) Butterworths Sci. Publ., London.

6) V. Lukeš, R. Komers, V. Herout, J. Chromatography 3 , 303 (1960).

7) A. T. James, A. J.P. Martin, Biochem. J. 50, 679 (1952).

8) M. Dimbat, P. E. Porter, F. H. Stross, Anal. Chem. 28, 290 (1956).

9) A.I. M. Keulemans, “ Gas Chromatography” p. 144 (1957) Reinhold Publ. Corp., New York.

10) W. J: Zubyk, A. Z. Conner, Anal. Chem. 32, 912(1960). 